\title{
Epigenetic modifications promote the expression of the orphan nuclear receptor NROB1 in human lung adenocarcinoma cells
}

\author{
Yongjie Lu ${ }^{1, *}$, Yunqiang Liu ${ }^{1, *}$, Shunyao Liao ${ }^{2, *}$, Wenling Tu ${ }^{1}$, Ying Shen ${ }^{1}$, Yuanlong \\ Yan ${ }^{1}$, Dachang Tao ${ }^{1}$, Yilu Lu ${ }^{1}$, Yongxin Ma ${ }^{1}$, Yuan Yang ${ }^{1}$, Sizhong Zhang ${ }^{1}$ \\ ${ }^{1}$ Department of Medical Genetics and Division of Human Morbid Genomics, State Key Laboratory of Biotherapy, West China \\ Hospital, West China Medical School, Sichuan University, Chengdu, Sichuan Province, China \\ ${ }^{2}$ Diabetic Center and Institute of Transplantation, Sichuan Academy of Medical Science \& Sichuan Provincial People's Hospital, \\ School of Medicine, University of Electronic Science and Technology of China, Chengdu, Sichuan Province, China \\ "These authors have contributed equally to this work \\ Correspondence to: Yunqiang Liu, email: yq_liu@scu.edu.cn \\ Keywords: NROB 1, lung adenocarcinoma, DNA methylation, histone modifications, cell self-renewal \\ Received: March 03, $2016 \quad$ Accepted: April 15, $2016 \quad$ Published: April 26, 2016
}

\section{ABSTRACT}

The ectopic activation of NROB1 is involved in the development of some cancers. However, the regulatory mechanisms controlling NROB1 expression are not well understood. Therefore, the epigenetic modifications promoting NROB1 activation were examined in this study. NROB1 protein was detected in cancerous tissues of more than $50 \%$ of human lung adenocarcinoma (ADCA) cases and tended to be expressed in low-differentiated cancerous tissues obtained from males. Nevertheless, NROB1 activation in ADCA has not previously been correlated with DNA demethylation. NROB1 expression was not detected in $293 \mathrm{~T}$ cells, although it contains a hypomethylated NROB1 promoter. Treating $293 \mathrm{~T}$ cells with a histone deacetylase inhibitor increased acetylated histone $\mathrm{H} 4$ binding to the NROB1 promoter and activated NROB1 expression. In contrast, treatment with histone methylase inhibitors decreased the methylation of histones H3K9 and H3K27 and slightly induced NROB1 transcription. Furthermore, the level of acetyl-histone $\mathrm{H} 4$ binding to the NROB1 promoter increased, whereas the occupancy of H3K27me3 was lower in cancerous tissues than in non-cancerous tissues. Similar histone occupancies were confirmed in a comparison of cancerous tissues with strong, moderate and negative NROB1 expression. In conclusion, this study shows that CpG methylation within the NROB1 promoter is not involved in the in vivo regulation of NROB1 expression, whereas the hyperacetylation of histone $\mathrm{H} 4$ and the unmethylation of histones H3K9 and H3K27, and their binding to the NROB1 promoter results in decondensed euchromatin for NROB1 activation.

\section{INTRODUCTION}

Nuclear receptor subfamily 0 group $B$ member 1 (NROB1), which is located on the $\mathrm{X}$ chromosome, is abundantly expressed in normal reproductive testicular and ovarian tissues. The precise levels and timing of NROB1 gene expression are critical for gonadal differentiation and sex determination during embryogenesis [1]. In addition, $N R O B 1$ is ectopically activated in several types of cancers, including endometrial carcinoma [2], ovarian carcinoma [3], prostate carcinoma [4], Ewing's sarcoma [5, 6], lung adenocarcinoma (ADCA) [7], breast cancer [8] and hepatocellular carcinoma [9]. Thus, $N R O B 1$ is regarded as a typical X-linked cancer/germline gene (CG-X).

To date, the expression of CG-X genes has commonly been thought to be controlled by epigenetic modifications, especially associated with the demethylation of critical $\mathrm{CpG}$ residues within their promoter regions [10]. Is the activation of the $N R O B 1$ gene in cancerous tissues under the control of active DNA demethylation? Oda et al reported that the expression level of $N R O B 1$ was inversely correlated with the proportion of methylated $\mathrm{CpG}$ sites within the $N R O B 1$ promoter in ADCA [7], suggesting that DNA methylation is involved 
in the activation of $N R O B 1$ in ADCA. However, this correlation was not observed in our specimens. The CpG sites within the NROB1 gene promoter were almost unmethylated in the in vivo tissues and cells obtained from males, independent of NROB1 expression status. This preliminary result indicates that the hypomethylation of $\mathrm{CpG}$ sites within the NROB1 gene promoter is not sufficient to trigger $N R O B 1$ expression in ADCA. Hence, it is not yet known what causes the activation of $N R O B 1$ in ADCA.

To address this issue, we thoroughly investigated the epigenetic modifications, including DNA methylation and histone modifications, within the $N R O B 1$ promoter region that regulates its gene expression in clinical ADCA samples and cultured cells. Furthermore, based on the level of NROB1 expression in ADCA cells with different clinical stages, our results indicate that epigenetic modifications promote $N R O B 1$ activation to maintain the self-renewal of cancer cells.

\section{RESULTS}

\section{NR0B1 expression tends to be activated in male ADCA tissues with low differentiation}

The ectopic activation of NR0B1 was investigated in 160 ADCA cases using IHC analysis. The NR0B1 signal was present in 87 cases $(54.37 \%$ of a total of 160 cases, Table 1) and was detected in both the nucleus and the cytoplasm of ADCA cells but not in the paired adjacent noncancerous lung cells (Figure $1 \mathrm{~A}-1 \mathrm{~F}$ ). Notably, the NR0B1 protein was expressed more frequently in males (53 of 83 cases, $63.86 \%$ ) than in females (34 of 77 cases, $44.16 \%$ ), with a $p$ value of 0.0124 (Table 1). Moreover, a strong NR0B1 signal was also more frequently present in males than in females ( $p=0.0070$, Table 1$)$.

In addition, the NR0B1 signal was observed in approximately one-half of the specimens obtained from clinical stage II and two-thirds of the specimens obtained from stage III patients, but it was not detected in any of the 5 stage I patients (Figure $1 \mathrm{G}-1 \mathrm{H}$, Table 1). In particular, the NR0B1 signal was significantly stronger in the tissues obtained from male cases of stage III than in those obtained from male stage II patients, whereas no difference was observed in NR0B1 expression between clinical stages in females $(p=0.049$ for males, $p=0.937$ for females, Table 1). Furthermore, immunoblotting analysis of whole protein that were extracted from male cancerous tissues at stages II and III confirmed that the NR0B1 protein was expressed at higher levels in the poorly differentiated cases that were stage III (Figure 1I-1J).

\section{NR0B1 expression in ADCA does not result from active DNA demethylation in the $\mathrm{CpG}$ island (CGI) region of the $N R O B 1$ gene}

The methylation pattern of the NROB1 CGI was investigated in cancerous and paired adjacent noncancerous tissues using 10 cases of ADCA, including 5 males and 5 females. Bisulfite sequencing revealed that almost all of the $\mathrm{CpG}$ sites were unmethylated in both the cancerous and the noncancerous tissues obtained from male cases, and more than $50 \%$ of the $\mathrm{CpG}$ sites were unmethylated in those obtained from female cases. In particular, no significant difference was observed in the methylated $\mathrm{CpG}$ level between cancerous and noncancerous tissues (Figure 2A-2B). Furthermore, the hypomethylated status of $N R O B 1$ CGI was confirmed in the NR0B1-negative cancerous tissues that were obtained from another 10 male and female cases (Figure 2C).

Additionally, the methylation pattern of the NROB1 CGI was investigated in normal tissues and cells from males and females. The peripheral blood from 10 healthy subjects without $N R O B 1$ transcription and the testis tissues of 2 obstructive azoospermic patients with normal spermatogenesis and $N R O B 1$ transcription were examined. Similarly, the CpG sites were not frequently methylated in male blood and testis, and less than half of the $\mathrm{CpG}$ sites were methylated in female blood (Figure 2D). Given that females have two copies of the $N R O B 1$ gene, the increased methylation level in females may reflect $\mathrm{X}$ inactivation.

Due to the limitations associated with using human samples, the relationship between DNA methylation and $N R O B 1$ expression could not be verified in multiple human tissues. Therefore, the methylation status of the homologous $\mathrm{NrOb1}$ CGI was examined in mouse tissues and cells using pyrosequencing analysis. The results also indicated that the $\mathrm{CpG}$ sites in the $\mathrm{NrObl}$ gene were hypomethylated (methylation rate: $0 \sim 30 \%$ ) in the heart, liver, brain, lungs, pancreas and peripheral leukocytes of male mice, and the average methylation ratio was also less than $40 \%$ in the parallel tissues and cells of female mice (Supplementary Figure S1). Similarly, the methylation level of the NrObl CGI was not different between testis tissues with NrObl expression and other tissues without $\mathrm{NrObl}$ expression in male mice or between ovarian tissues and other tissues in female mice (Supplementary Figure S1-S2). Furthermore, the methylation level of the $\mathrm{CpG}$ sites in the $\mathrm{NrOb1}$ promoter did not obviously change as the expression of $\mathrm{NrObl}$ shifted during embryogenesis and testis development (Supplementary Figure S1-S2). These results in mice are in agreement with those obtained in humans, indicating that DNA methylation is not involved in the regulation of NROB1/NrOb1 gene expression in vivo. 
Table 1: NROB1 expression profile in the human lung adenocarcinoma samples with different clinical stage

\begin{tabular}{|c|c|c|c|c|c|}
\hline & & \multicolumn{3}{|c|}{ No. of Cases with different NR0B1 signal level } & \multirow[t]{2}{*}{$p$ value $^{\text {a }}$} \\
\hline & & Strong $(++)$ & Moderate $(+)$ & Negative (-) & \\
\hline \multirow{2}{*}{ Gender } & Male & 30 & 23 & 30 & $0.0124^{b *}$ \\
\hline & Female & 15 & 19 & 43 & $0.0070^{\mathrm{c} * *}$ \\
\hline \multirow{3}{*}{ Clinical Stage } & $\mathbf{I}$ & 0 & 0 & $5(2)$ & $0.0925^{\mathrm{e}}$ \\
\hline & II & $28(19)^{\mathrm{d}}$ & $32(18)^{\mathrm{d}}$ & $55(25)^{\mathrm{d}}$ & $0.0492^{\mathrm{f} *}$ \\
\hline & III & $17(11)^{\mathrm{d}}$ & $10(5)^{\mathrm{d}}$ & $13(3)^{\mathrm{d}}$ & $0.9366^{\mathrm{g}}$ \\
\hline
\end{tabular}

a Pearson's chi-squared test is applied in the calculation. * $p$ value $<0.05, * * p$ value $<0.01$

${ }^{\mathrm{b}, \mathrm{c}}$ The $p$ value is calculated by comparing the number of male and female cases ${ }^{\mathrm{b}}$ between NR0B1-positive group $(++$ and +$)$ and -negative group (-) and ${ }^{\mathrm{c}}$ between NR0B1-strong group (++) and -negative group.

d The number in the parentheses is that of male cases.

e-gThe $p$ value is calculated by comparing the number of ${ }^{\mathrm{e}}$ both male and female cases, ${ }^{\mathrm{f}}$ only male cases, and ${ }^{\mathrm{g}}$ only female cases, of the stage II and III between NR0B1-positive group and negative group.

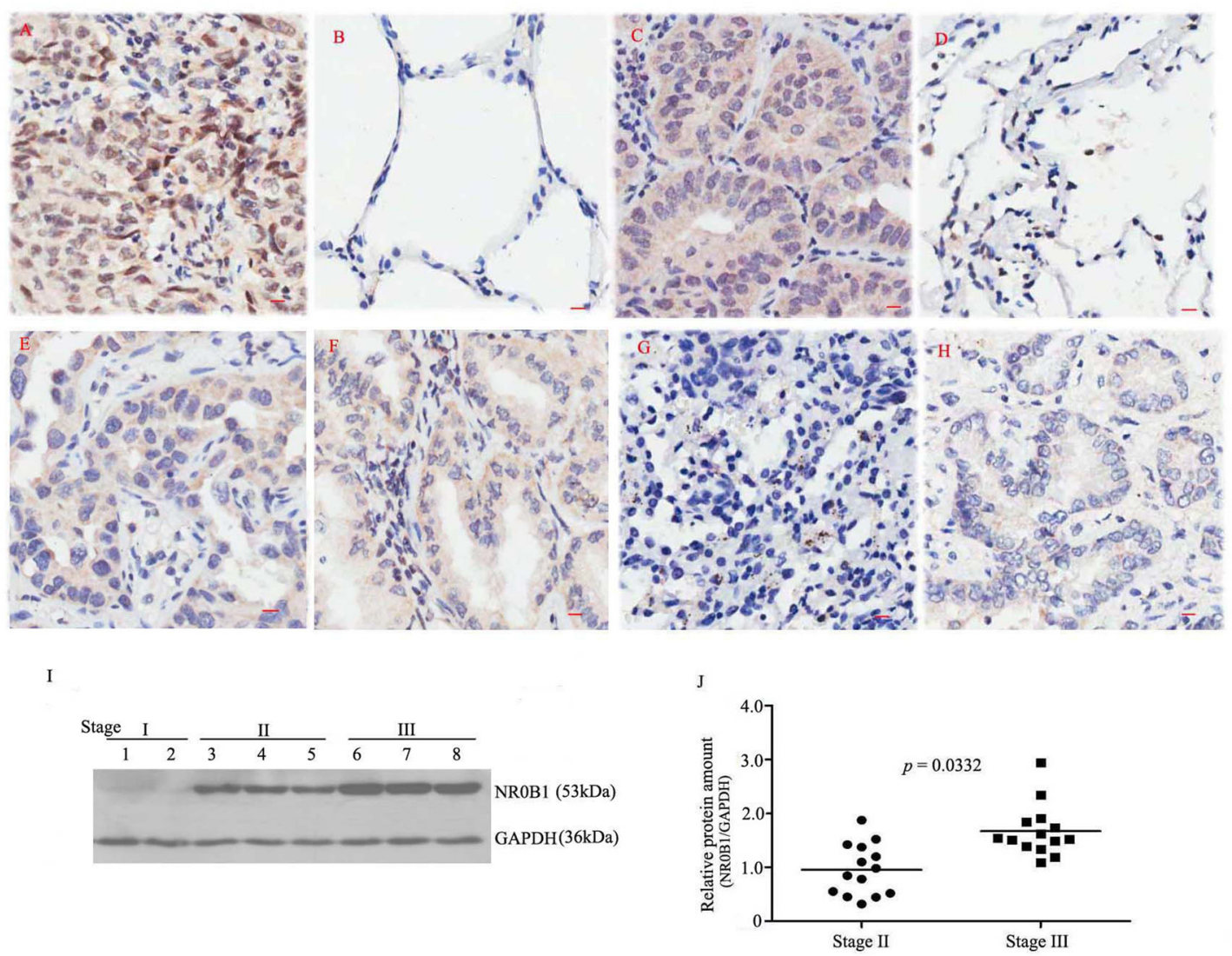

Figure 1: Expression profile of the $N R O B 1$ protein in human lung adenocarcinoma samples. A. An example showing strong NR0B1-positive staining in cancerous tissue from a male case of clinical stage III cancer but not in the adjacent non-cancerous tissue B, C. An example showing strong NR0B1-positive staining in cancerous tissue from a female case of clinical stage III cancer but not in the adjacent non-cancerous tissue D, E-F. An example showing a moderate immunoreactive signal for NR0B1 in the cancerous tissues from one male case (E) and one female case (F) of clinical stage II cancer. G-H. Representative image showing NR0B1-negative staining in cancerous tissues (from one female case in stage III (G) and one male case in stage I cancer $(\mathrm{H})$ ). Scale bar $=10 \mu \mathrm{m}$. I. Varying amounts of NR0B1 protein were detected in different male cancerous tissues that were obtained from several representative cases of stages I, II and III cancer and analyzed using immunoblotting. J. Relative NR0B1 protein levels (versus GAPDH) in male cancerous tissues in stage II and stage III (14 cases/stage). The results showed that the NR0B1 protein was present at a higher level in the male stage III cancerous tissues than the male stage II cancerous tissues. 


\section{Hypermethylated NROB1 CGI silences its expression in vitro}

Despite the fact that DNA methylation was not correlated with in vivo NROB1 gene expression, a relationship was observed between $N R O B 1$ expression and CGI methylation status in several cultured cells. For example, NROB1 was expressed in A549, DU145 and SKOV-3 cells, all of which contain a hypomethylated NROB1 CGI, whereas NROB1 was not present in HepG2, LNCaP, PC-3, MCF7 and HeLa cells, which contain a hypermethylated NROB1 CGI (Figure 3). Meanwhile, the expression of NROB1 in PC-3 and MCF7 cells and mouse $\mathrm{NrOb1}$ in GC-1 cells was activated by treating the cells with the DNA methyltransferase inhibitor AZA (Figure 4A, Supplementary Figure S3A). Subsequent bisulfite sequencing and pyrosequencing confirmed that the NROB1/NrOb1 CGI was demethylated in PC-3, MCF7 and GC-1 cells after AZA treatment (Figure 4B, Supplementary Figure S3B).
To further examine the effect of the methylation status of the $N R O B 1 / \mathrm{NrOb1}$ CGI on the regulation of gene expression in vitro, the $5^{\prime}$ upstream sequences of NROB1 and its mouse homolog NrObl were sub-cloned into a $\mathrm{CpG}$-free luciferase reporter vector. After in vitro methylation treatment with $\mathrm{CpG}$ methyltransferase, the luciferase activity of the methylated $\mathrm{NROB1}$ and $\mathrm{NrOb1}$ constructs was clearly repressed (Supplementary Figure S4A-S4B), in agreement with the results described in a previous report [7]. These results demonstrate that DNA methylation is involved in the regulation of $\mathrm{NROB1/NrOb1}$ expression in vitro and that hypermethylating the $N R O B 1$ CGI silences the expression of this gene in cultured cells.

\section{Acetyl-histone $\mathrm{H} 4$ binding to the NROB1 gene promoter activates its expression}

While investigating the correlation between NROBI expression and its promoter CGI methylation in cultured cells, we unexpectedly found that the transcription of the

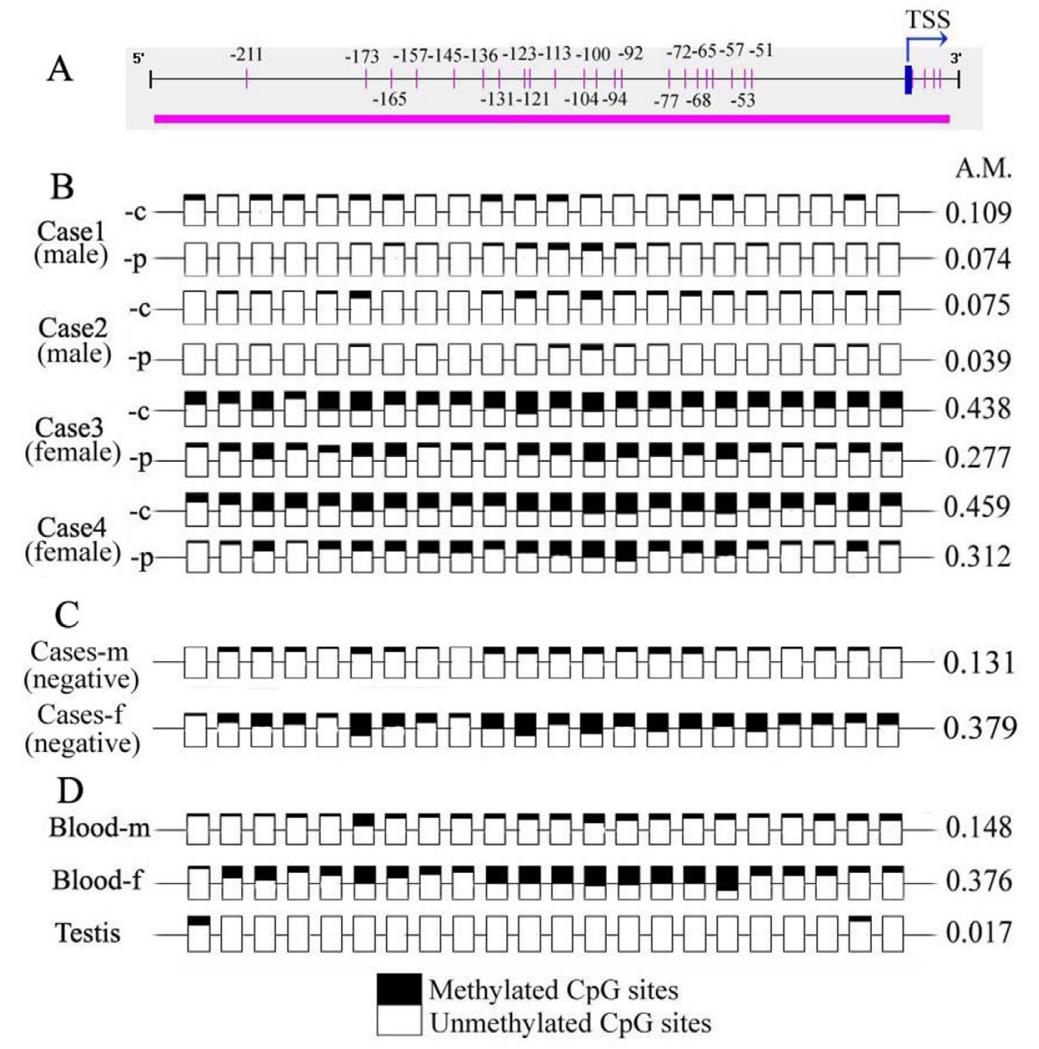

Figure 2: Methylation status of $\mathrm{CpG}$ sites within the $\mathrm{NROB1}$ promoter in human samples. A. Scheme showing the CpG sites within the NROB1 promoter. The numbers indicate the positions of the CpG sites, with the transcription start site (TSS) considering to be +1 . B. The pattern of methylation of the NROB1 CpGs in cancerous (-c) and normal non-cancerous (-p) tissues in male and female lung adenocarcinoma cases. Cases 1 and 3: Clinical stage III with strong NR0B1 expression; and cases 2 and 4: stage II with moderate NR0B1 expression. C. Cases (negative) showing a mixture of cancerous tissues with a negative NR0B1 signal from $10 \mathrm{male}(-\mathrm{m})$ and female (-f) cases, respectively. D. The NROB1 methylation status is shown for the genomic DNA from male (-m) and female (-f) peripheral blood and testis samples. Empty squares indicate unmethylated cytosine residues, and shaded squares indicate methylated cytosine residues. A.M.: average ratio of methylated $\mathrm{CpG}$ sites. 
A

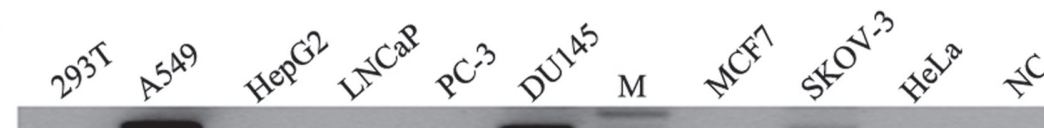

$\longrightarrow-\infty=0-\infty=0$

$\mathrm{B}$

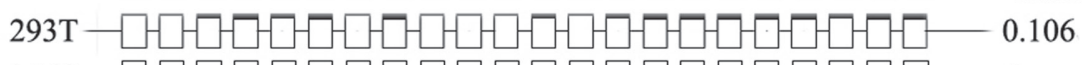
А549 - ㅁㅁㅁㅁㅁㅁㅁㅁㅁㅁㅁㄴ 0

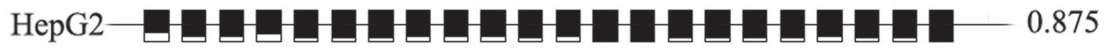

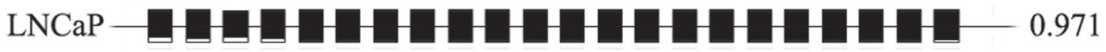

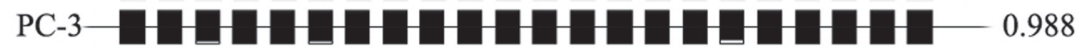

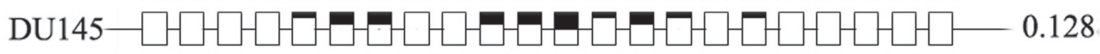

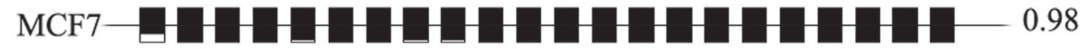

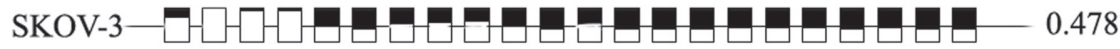

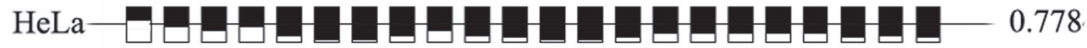

Figure 3: Correlation analysis of $N R 0 B 1$ expression with its CGI methylation status in nine cell lines. A. The NROBI mRNA was detected using RT-PCR in A549, DU145 and SKOV-3 cells but not in 293T, HepG2, LNCaP, PC-3, MCF7 and HeLa cells. NC: Water acted as a negative control for the RT-PCR template. B. Relative methylated levels of the NROB1 CGIs in different cells. M: DNA ladder. A.M.: average ratio of methylated $\mathrm{CpG}$ sites.

A

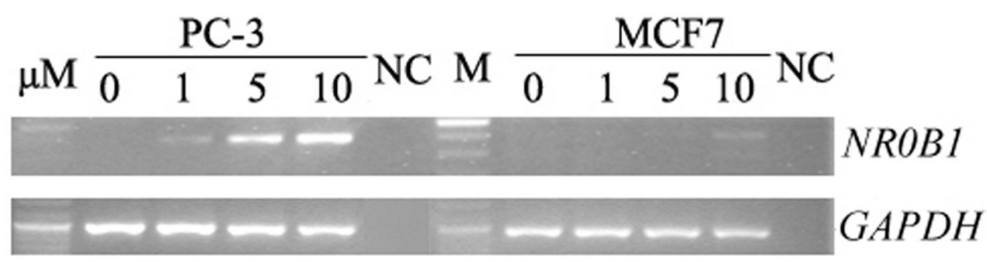

B

$\mu \mathrm{M}$

PC-3

A.M.

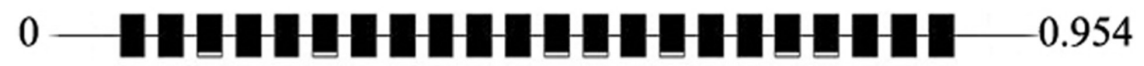

1 - 0.905

5 - G

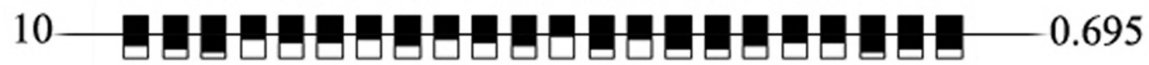

MCF7

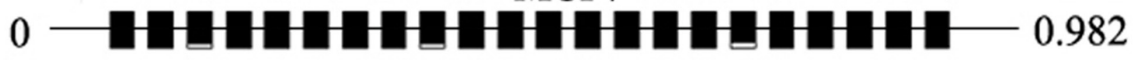

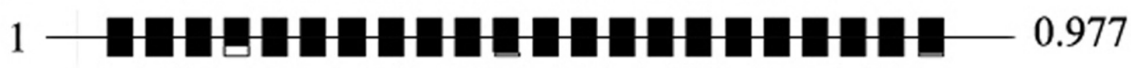

5 - G

10 - 0.889

Figure 4: DNA demethylation activates NROB1 expression. A. The expression of NROB1 was activated in PC-3 and MCF7 cells that were treated with the DNA methyltransferase inhibitor AZA. NC: Water acted as a negative control for the RT-PCR template. B. NR0B1 CGI was partially demethylated in cells that were treated with AZA. A.M.: average ratio of methylated CpG sites. 
NROB1 gene was almost undetectable in $293 \mathrm{~T}$ cells, even though the NROB1 CGI was slightly methylated (Figure $3 \mathrm{~A}-3 \mathrm{~B})$. The features of the $N R O B 1$ gene were similar in 293T cells to those that were observed in male tissues and cells in vivo. Thus, 293T cells were selected to explore the effect of other epigenetic factors, such as histone modifications, on the expression of the NROB1 gene. To evaluate the contribution of histone acetylation to the epigenetic regulation of the $N R O B 1$ gene, the common histone deacetylase (HDAC) inhibitor TSA was used to treat $293 \mathrm{~T}$ cells. Interestingly, the expression of the NROBI gene was activated after treatment with TSA, and the upregulation of $N R O B 1 \mathrm{mRNA}$ occurred in a dose-dependent manner, with maximal induction observed at a TSA dose of $300 \mathrm{ng} / \mathrm{mL}$ (Figure $5 \mathrm{~A}$ ).

Considering that the expression of NROB1 is under the control of a cross-talking network that involves transcriptional factors such as NANOG,
OCT3/4, androgen receptor (AR), NR5A1 (also named steroidogenic factor 1), NR5A2 (also named liver receptor homolog-1), SOX2 and STAT3 during embryogenesis in addition to the production of steroid hormones [11-15], we next analyzed changes in these factors in $293 \mathrm{~T}$ cells that were treated with TSA. As shown in Figure 5B and 5C, the expression levels of AR, NR5A1, NR5A2 and SOX2 were significantly increased after treatment. Because these four trans-acting factors can promote $N R O B 1$ expression, we investigated whether $N R O B 1$ activation resulted from an enrichment of related trans-acting factor(s) in TSAtreated $293 \mathrm{~T}$ cells. To address this question, expression vectors containing AR, NR5A1, NR5A2 and SOX2 were transfected into $293 \mathrm{~T}$ cells. Unexpectedly, NROB1 expression was not altered by the over-expression of $A R$, NR5A1, NR5A2 or SOX2 individually, or by the overexpression of all 4 factors together in the same cells (Supplementary Figure S5A-S5B).
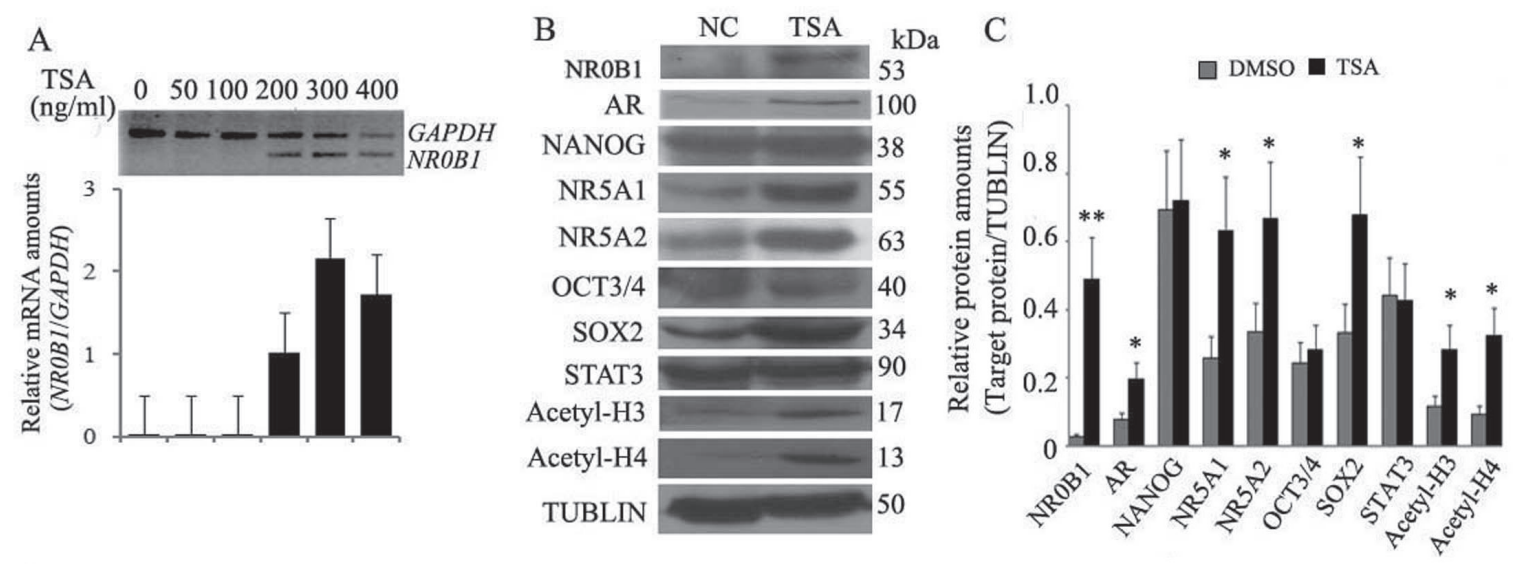

$\mathrm{D}$

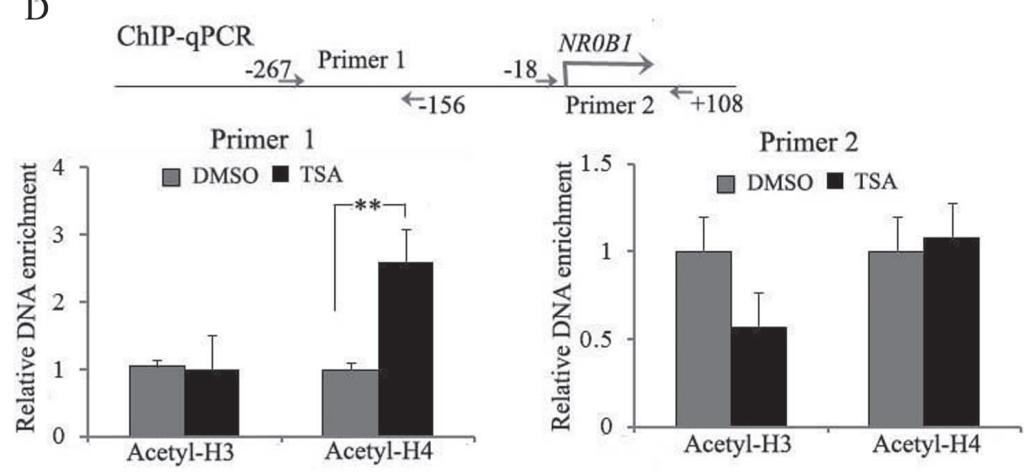

Figure 5: Histone $\mathbf{H} 4$ acetylation promotes $N$ ROB1 gene expression. A. The expression of $N R 0 B 1$ mRNA was activated in $293 \mathrm{~T}$ cells that were treated with the HDAC inhibitor TSA (upper panel: gel electrophoresis results of RT-PCR; low panel: qRT-PCR results). B. Protein levels of acetyl-histone $\mathrm{H} 3$ and $\mathrm{H} 4$ and the transcription factors AR, NANOG, NR5A1, NR5A2, OCT3/4 and SOX2 were compared before and after TSA treatment in 293T cells. TUBULIN acted as an internal control. C. Relative protein amounts (versus TUBULIN) of NR0B1, acetyl-histone H3 and H4, AR, NANOG, NR5A1, NR5A2, OCT3/4 and SOX2 in 293T cells before and after TSA treatment. D. ChIP-qPCR analysis of the NROB1 promoter region using anti-acetyl-histone H3 and H4 antibodies in 293T cells before and after TSA treatment. The promoter region from -267 to -156 of the NROB1 gene was significantly enriched in TSA-treated 293T cells, as detected using anti-acetyl-histone $\mathrm{H} 4$ antibodies. ${ }^{*} p$ value $<0.05$ and ${ }^{* *} p$ value $<0.01$ in the Student's $t$-test. 
Furthermore, a ChIP-qPCR assay showed that acetylated histone $\mathrm{H} 4$ binding to the promoter region of the NROB1 gene was enriched in 293T cells after treatment with TSA (Figure 5D), whereas the amount of acetylated histone $\mathrm{H} 3$ binding to the $N R O B 1$ promoter sequence was not significantly changed. Thus, the enrichment of acetylhistone $\mathrm{H} 4$ binding to the $N R O B 1$ promoter region is likely to be one mechanism that facilitates its expression in $293 \mathrm{~T}$ cells.

\section{Histone acetylation synergistically up-regulates NROB1 gene expression on top of DNA demethylation in vitro}

We next investigated whether TSA can activate the expression of the NROB1 gene in human cells with a hypermethylated $N R O B 1$ CGI. AZA and TSA have been previously reported to act synergistically during the activation of cancer-related genes [16, 17], and TSA can induce the DNA demethylation of some genes [18, 19]. PC-3 and MCF7 cells were treated with
TSA alone or in combination with AZA. As shown in Figure 6A-6B, TSA treatment alone did not induce $N R O B 1$ expression, whereas the combination of AZA and TSA resulted in 4.5- and 3.5-fold higher NROB1 expression in PC-3 and MCF7 cells, respectively, than was produced by treatment with AZA alone. Subsequent bisulfate sequencing of PC-3 cells demonstrated that the methylation status of the NROB1 CGI was not changed by treatment with TSA. In addition, its methylation levels were decreased following treatment with AZA alone and when cells were treated with a combination of AZA and TSA (Figure 6C). However, the demethylation level observed in PC-3 cells that were exposed to both AZA and TSA was not different from the level observed in cells treated with AZA alone (Figure 6C). These results indicate that the higher fold change that was observed in NROB1 expression following combined treatment with AZA and TSA could be the result of synergistic action between histone acetylation and DNA demethylation in cells containing a hypermethylated NROB 1 promoter.

A
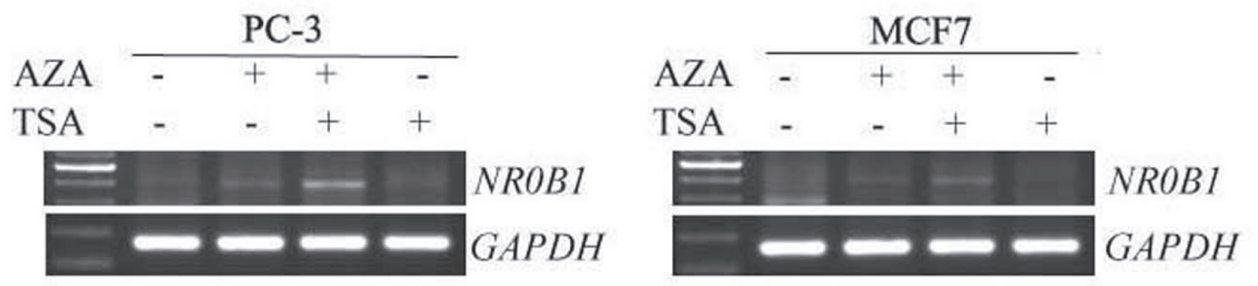

B
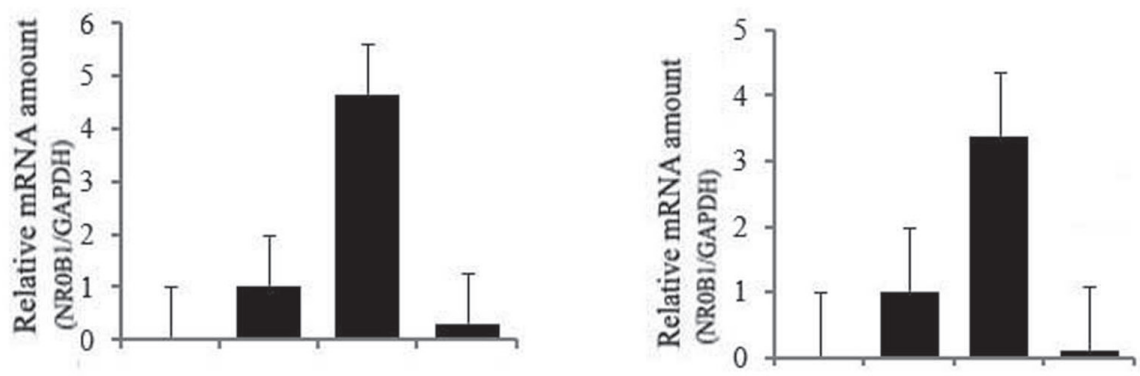

$\mathrm{C}$

A.M.

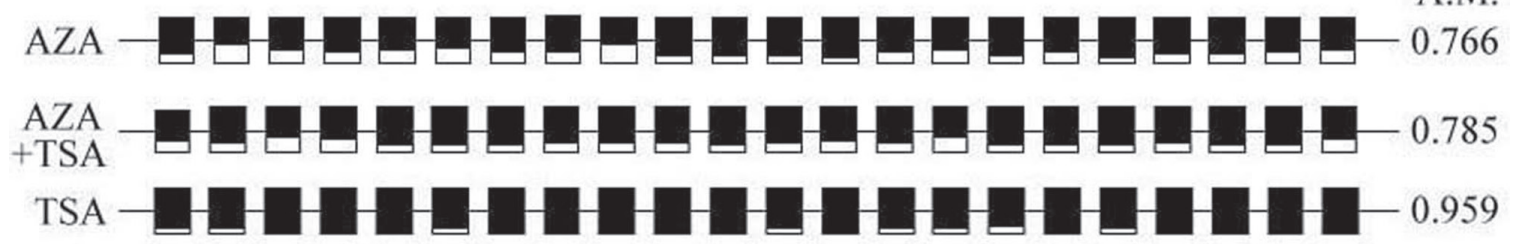

Figure 6: Synergistic effects of AZA and TSA on NROB1 gene activation. A-B. TSA further increased $N R O B 1$ expression in PC-3 and MCF7 cells to a higher level than treatment with AZA alone. Treatment with TSA alone did not activate NROB1 expression. C. The DNA methylation level of the NROB1 CGI in PC-3 cells that were treated with AZA, TSA alone, or a combination of AZA and TSA. A.M.: average ratio of methylated $\mathrm{CpG}$ sites. 


\section{Dimethylated histone H3 lysine 9 (H3K9me2) and trimethylated histone $\mathrm{H3}$ lysine 27(H3K27me3) binding to the NROB1 promoter are involved in silencing its expression}

We next investigated the role of histone lysine methylation on the expression of the NROB1 gene because histone lysine methylation also plays important roles in the organization of chromatin domains and the regulation of gene expression [20]. We treated 293T cells with two histone methyltransferase (HMTase) inhibitors: 3-deazaneplanocin A (DZNep), which selectively inhibits the trimethylation of lysine 27 on histone $\mathrm{H} 3$ [21], and BIX01294, which selectively impairs the G9a HMTase EHMT2 and the generation of methylated H3K9 [22]. Both DZNep and BIX01294 induced the expression of the NROB1 gene (Figure 7A-7B), although the level of induction was lower than that observed following TSA treatment. In addition, the HMTases EZH2 and EHMT2 were depleted in 293T cells after treatment with DZNep and BIX01294, respectively (Figure 7C). Furthermore, the levels of H3K27me3 and H3K9me2 were decreased in DZNep-treated cells, whereas only the H3K9me2 level was decreased in BIX01294-treated cells (Figure 7C). These results confirm that a higher level of $N R O B I$ expression is induced by treatment with DZNep than with
BIX01294 (Figure 7A-7B). These results also indicate that the methylation of $\mathrm{H} 3 \mathrm{~K} 9$ and $\mathrm{H} 3 \mathrm{~K} 27$ is involved in silencing the transcription of NROB 1 in 293T cells and vice versa.

\section{Histone modifications facilitates NROB1 gene expression}

To obtain a more comprehensive understanding of the histone modifications that promote $N R O B 1$ expression, we next compared the status of acetyl-histones $\mathrm{H} 3$ and $\mathrm{H} 4$ and methylated histones $\mathrm{H} 3 \mathrm{~K} 4 \mathrm{me} 3, \mathrm{H} 3 \mathrm{~K} 9 \mathrm{me} 2$ and $\mathrm{H} 3 \mathrm{~K} 27 \mathrm{me} 3$ binding to the $N R O B 1$ gene promoter in human tissues and cells with different $N R O B 1$ expression patterns. The ChIP-qPCR results showed that the level of acetyl-H4 binding to the $N R O B 1$ promoter in A549 cells with $N R O B 1$ expression was more than twenty-fold higher than the level in $293 \mathrm{~T}$ cells without NROB1 expression, whereas the occupancy of H3K9me2 and H3K27me3 were two-fold lower in A549 cells than in 293T cells (Figure 8A). Because the expression level of $N R O B 1$ was much higher in A549-SP cells than in A549-MP cells [7, Supplementary Figure S6], we compared acetyl-histone $\mathrm{H} 4, \mathrm{H} 3 \mathrm{~K} 9 \mathrm{me} 2$ and $\mathrm{H} 3 \mathrm{~K} 27 \mathrm{me} 3$ binding to the NROB1 promoter between A549-SP and A549-MP cells after both populations were sorted (Supplementary Figure S6). The

A

M DMSO TSA BIX DZNP A549 NC

E- - - -

B

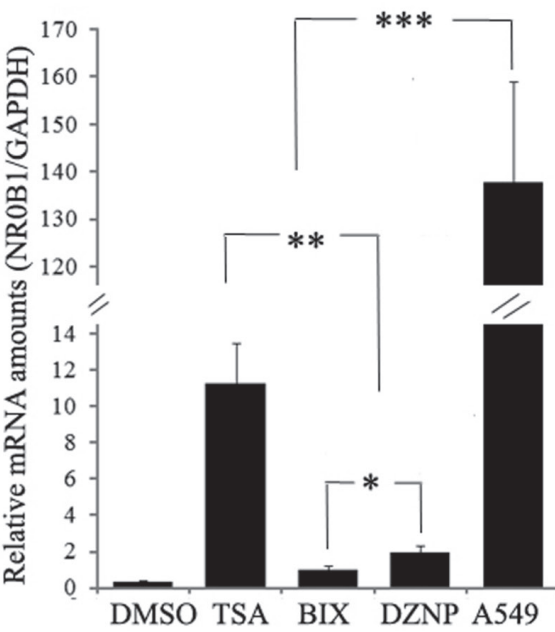

$\mathrm{C}$

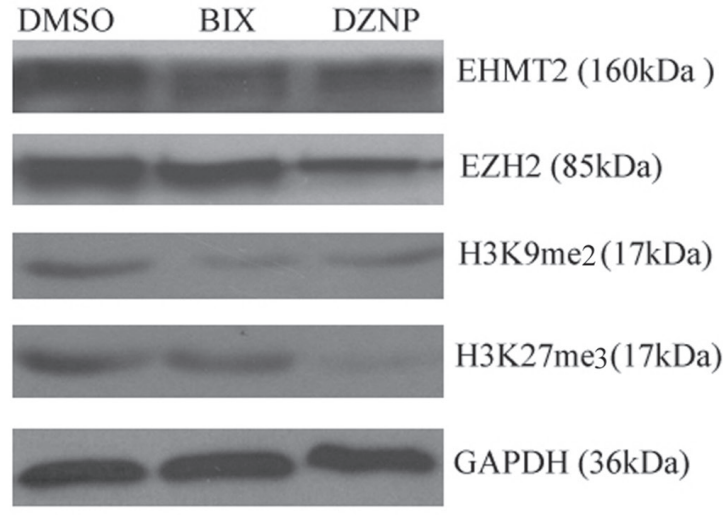

Figure 7: Effect of histone demethylation on NROB1 expression. A-B. Treatment with the histone methylase inhibitors DZNeP (DZNP) and BIX01294 (BIX) resulted in slightly higher levels of NROB1 expression in 293T cells than was induced by treatment with the vehicle (DMSO). A549 acted as a positive control and water was used as a negative control (NC) in the RT-PCR analysis. C. The protein levels of the DZNep target methylase EZH2, the BIX01294 target methylase EHMT2, and H3K9me2 and H3K27me3 were detected in 293T cells that were treated with DZNeP, BIX01294 or vehicle (DMSO). ${ }^{*} p$ value $<0.05,{ }^{* *} p$ value $<0.01$ and ${ }^{* * *} p$ value $<0.001$ using the Student's $t$-test. 
A

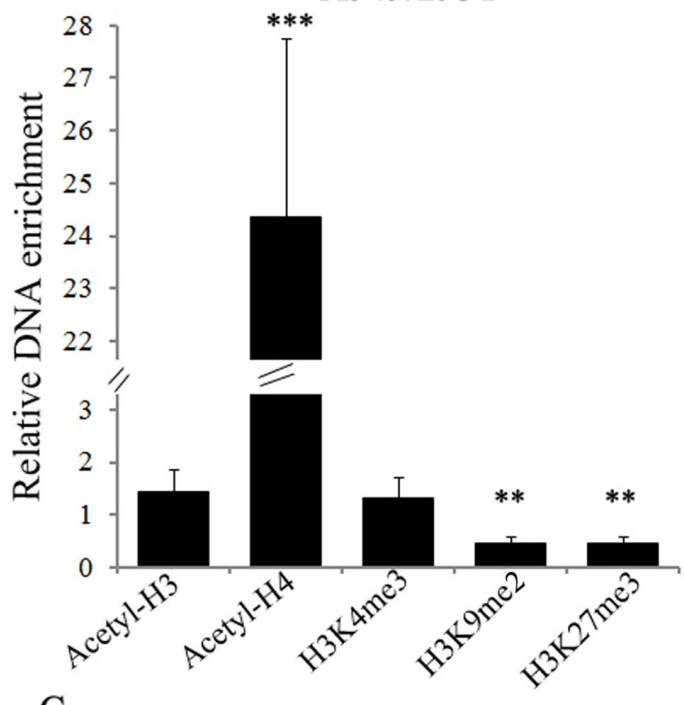

$\mathrm{C}$

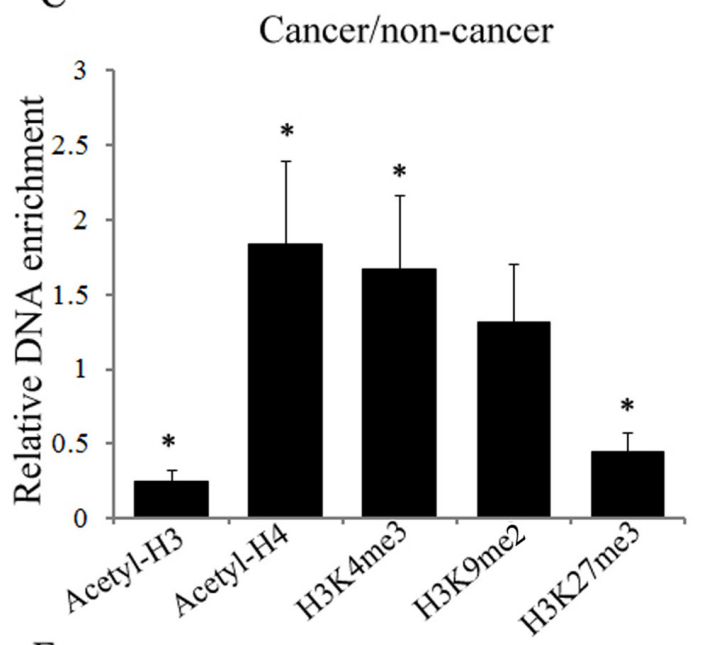
$\mathrm{E}$

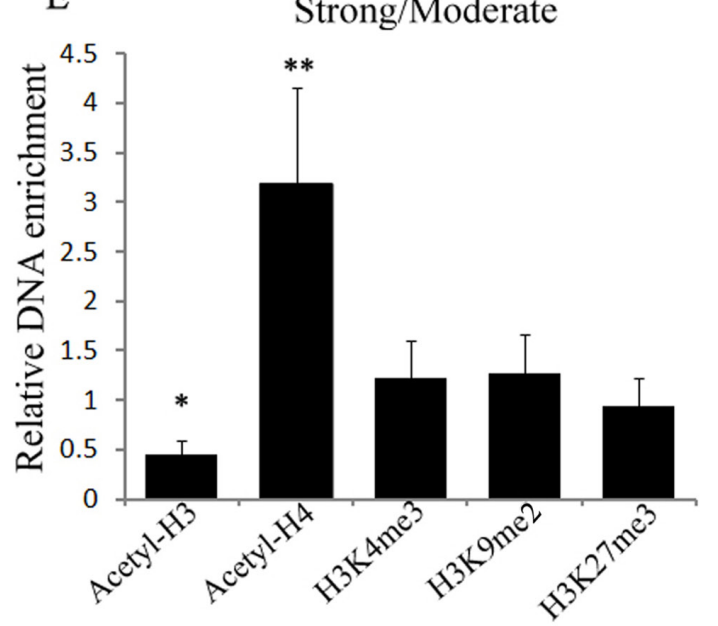

B
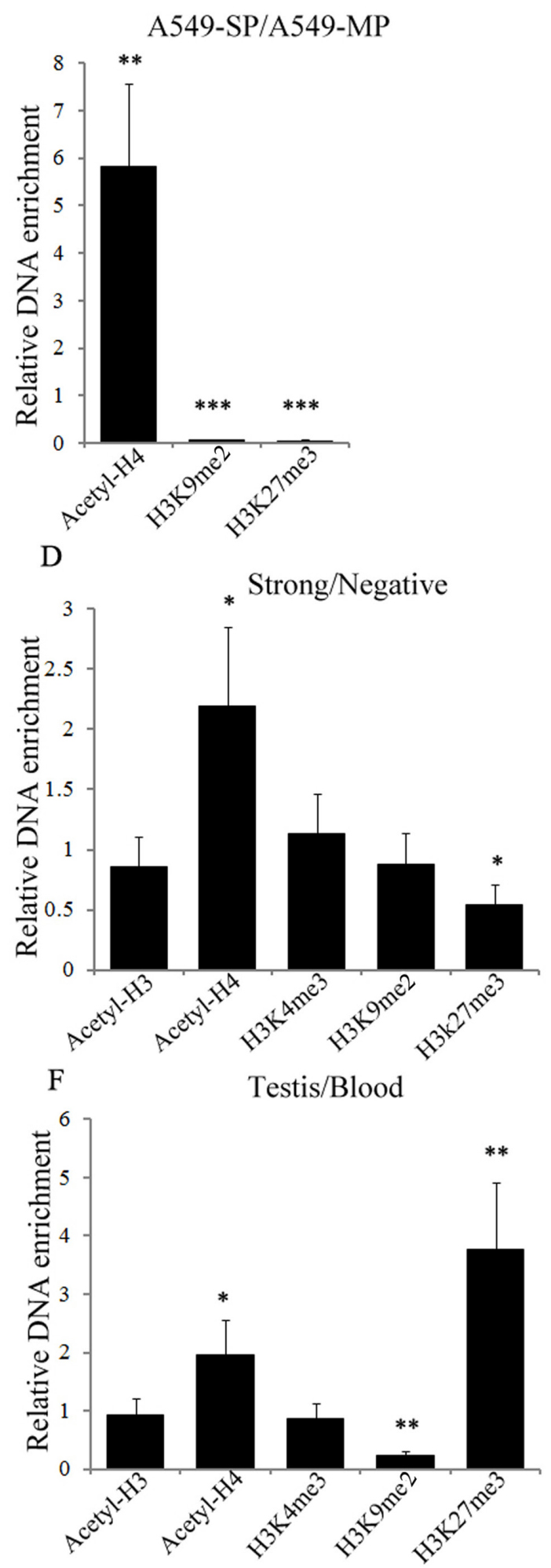

Figure 8: Histone modifications within the NROB1 promoter in different tissues and cells by ChIP-qPCR analysis. Different histone modifications were detected in the NROBI promoter region between 293T and A549 cells A. the side (SP) and main (MP) populations of A549 cells B. cancerous and non-cancerous tissues C. cancerous tissues with a strong and negative NR0B1 signal D. cancerous tissues with a strong and moderate NR0B1 signal E. and between testis tissues and peripheral blood F. The cancerous and non-cancerous tissues were mixed samples from 5 patients. ${ }^{*} p<0.05,{ }^{*} * p$ value $<0.01$ and $* * * p$ value $<0.001$ using the Student's $t$-test. 
results also showed that acetyl-H4 binding to the NROB1 promoter was approximately six-fold higher in A549SP cells than in A549-MP cells, whereas H3K9me2 and $\mathrm{H} 3 \mathrm{~K} 27 \mathrm{me} 3$ binding to the $N R O B 1$ promoter was minimal (Figure $8 \mathrm{~B}$ ). These results further confirm that acetylhistone $\mathrm{H} 4$ binding to the $N R O B 1$ promoter can promote NROB1 expression, whereas H3K9me2 and H3K27me3 occupancy prevents $N R O B 1$ expression in cultured cells.

We additionally examined the above histone modifications in human tissues and cells. Consistent with the results obtained in cultured cells, the occupancy of acetyl-histone $\mathrm{H} 4$ and $\mathrm{H} 3 \mathrm{~K} 4 \mathrm{me} 3$, which facilitate gene expression, was higher in cancerous tissues than in non-cancerous tissues, whereas the occupancy of H3K27me3 was lower in cancerous tissues (Figure 8C). Meanwhile, the acetyl-histone H4 occupancy level was also significantly higher in cancerous tissues with a strong NR0B1 signal than in those with negative or moderate NR0B1 expression (Figure 8D-8E). Histone modifications between blood cells and testis tissues also showed increased acetyl-histone $\mathrm{H} 4$ binding, and reduced $\mathrm{H} 3 \mathrm{~K} 9 \mathrm{me} 2$ binding to the $N R O B 1$ promoter was observed in testis tissues (Figure 8F). Hence, the above in vivo results were in agreement with those obtained in vitro, demonstrating that hyperacetylated histone $\mathrm{H} 4$ and demethylated histone $\mathrm{H} 3$ lysine 9 and 27 binding to the $N R O B 1$ promoter are necessary for the activation of $N R O B 1$ expression.

\section{DISCUSSION}

The orphan nuclear receptor NR0B1 is highly conserved in evolution from fish to mammals [23]. A large body of evidence obtained from experiments using animal models indicates that NR0B1 is involved in embryonic development and plays a role in the pluripotency and self-renewal capacity of embryonic stem (ES) cells. Self-renewal is an essential property of stem cells that allows them to maintain a stem cell pool. The expression of NR0B1 is regulated by STAT3, OCT3/4, NANOG, NR5A2 and estrogen receptor $\beta(E R \beta)$, all of which are essential transcription factors for ES cell self-renewal [14, 15, 24-26]. Recently, Fujii et al reported that NR0B1 is necessary for ES cell self-renewal because it represses the 2-cell-stage-specific protein Zscan4c [27]. In this study, the presence of NR0B1 was correlated with clinical stage in male ADCA. A high level of NR0B1 protein was detected in poorly differentiated male cases. Considering a higher level of expression of NR0B1 observed in SPthan in MP-derived A549 cells, we propose that NR0B1 may be involved in the process of maintaining the "stem characters" of ADCA cells and promoting self-renewal in cancer cells.

NR0B1 can act as a negative co-regulator of steroidogenic factor 1, liver receptor homolog-1, AR, $\mathrm{ER}$, and progesterone receptor (PR), and it plays a critical role in the biosynthesis of steroid hormones [28]. Gonadal steroids contribute to prostate, breast, and ovary carcinogenesis [29-31], among others. The plausibility of sex hormone involvement in ADCA is also supported by the significantly higher expression of ER and PR that were observed in ADCA than in other lung cancer cell types [32-34]. In this study, the NR0B1 signal was detected in more than $50 \%$ of the cases of ADCA, indicating that the activation of NR0B1 in lung adenocells can promote carcinogenesis by turning on the abovementioned signal transduction systems, including steroid hormones. Unfortunately, the levels of AR, ER and PR were not examined in this study. Further investigation into the correlations between NR0B1 and the above steroid hormone receptors will help to clarify their role in the tumorigenesis of ADCA.

In this study, more NR0B1-positive cases were observed in male than in female ADCA cases. This novel result has not previously been reported. The differential expression of NR0B1 by gender conforms to the gender difference that has been observed in the prevalence of lung cancer, even when the increase of female lung cancer prevalence is taken into account. Thus, we hypothesized that in males, NR0B1 is more easily activated than in females because of its haploid (hemizygote) state. The in vitro data from AZA and TSA treatment experiments indicate that NR0B1 expression can be easily induced in cells derived from males, such as PC-3, 293T and GC-1 cells.

The hypomethylation of genomic DNA is associated with the activation of $\mathrm{CG}-\mathrm{X}$ genes with rich $\mathrm{CpG}$ residues in their promoter regions during the development of cancer [35]. Although a correlation between DNA methylation and $N R O B 1$ expression was previously suggested in ADCA patients, the gender of the cases that were used for bisulfite sequencing was not shown, and only 6 clones per case were sequenced [7]. However, in the current study, the sequences of more than 20 clones per sample were analyzed. Our results indicate that the $\mathrm{CpG}$ sites within the $N R O B 1$ promoter were almost unmethylated in the tissues and cells obtained from males, whereas fewer than $50 \%$ were unmethylated in the tissues and cells obtained from females, independent of the expression status of the $N R O B 1$ gene. In particular, no significant difference was observed in the $\mathrm{CpG}$ methylation level of the NROB1 promoter in the tissues obtained from the same gender. This methylation pattern has reserved during evolution, as revealed by investigations of the mouse $\mathrm{NrOb1} \mathrm{CGI}$ in multiple tissues and cells. These data indicate that DNA methylation may not be a triggering factor in the regulation of $N R O B 1$ expression in vivo. However, in cultured cells, $N R O B 1$ expression was silent once its CGI became hypermethylated. Thus, we propose that the unmethylated status of NROB1 CGIs may be necessary, but not sufficient, to induce the transcriptional activation of the $N R O B 1$ gene. 
Acetylated histones enhance chromatin decondensation and DNA accessibility, inducing transcriptional activation. In this study, hypomethylated NROB1 CGIs alone were not sufficient to induce its transcriptional activation, but treatment with the HDAC inhibitor TSA induced the expression of NROBI in cells with hypomethylated NROB1 CGIs, and treatment with TSA further promoted $N R O B 1$ expression higher than DNA demethylation with AZA treatment in cells with hypermethylated NROB1 CGIs. These observations indicate that histone acetylation status plays an important role in regulating $N R O B 1$ expression. When the $N R O B 1$ promoter contains a low level of acetyl-histone H4, its transcription cannot be activated by over-expressing the transcriptional factors AR, NR5A1, NR5A2 and SOX2 because they cannot be recruited to the binding sites on the NROB1 promoter. Our ChIP-qPCR results further confirmed that the acetyl-histone H4 occupancy level was correlated with the expression pattern of the NROB1 gene in all of the studied tissues and cells. Histone H4 is typically acetylated at lysines 5, 8, 12, and 16 [36], and the acetylated histone $\mathrm{H} 4$ can prevent its lysine 20 trimethylation, resulting in transcriptionally active euchromatin [37]. Moreover, the structure of acetylated histone $\mathrm{H} 4$ indicates that it can be recognized by the Bromodomain-PHD finger module of the human transcriptional co-activator CBP [38], which is involved in a signaling pathway during lung tumorigenesis [3942]. Thus, we propose that hyperacetylated histone H4, in cooperation with $\mathrm{CBP}$, promotes the transcription of NROB1 in ADCA.

Methylated $\mathrm{H} 3 \mathrm{~K} 27$ and $\mathrm{H} 3 \mathrm{~K} 9$ are considered hallmark signatures of condensed heterochromatin that down-regulates neighboring gene expression [43]. In this study, treatment with HMTase inhibitors activated the expression of NROB1 in 293T cells. ChIP-qPCR results revealed high levels of $\mathrm{H} 3 \mathrm{~K} 9 \mathrm{me} 2$ and $\mathrm{H} 3 \mathrm{~K} 27 \mathrm{me} 3$ at the promoter region of the NROB1 gene in 293T and A549MP cells, in which $N R O B 1$ was expressed at low levels, whereas the NROB1 CGI was hypomethylated. This result suggests that $\mathrm{H} 3 \mathrm{~K} 9 \mathrm{me} 2$ or $\mathrm{H} 3 \mathrm{~K} 27 \mathrm{me} 3$ binding to the NROB 1 promoter is critical for inhibiting its transcription. Additionally, a higher level of $\mathrm{H} 3 \mathrm{~K} 27 \mathrm{me} 3$ binding to the $N R O B 1$ promoter was found only in non-cancerous tissues and cancer tissues with negative $N R O B 1$ expression and not in cancer tissues with a strong NR0B1 signal. Higher H3K9me2 occupancy was observed only in peripheral leukocytes and not in testis tissues. This result suggests that the methylation of both lysines 9 and 27 in histone $\mathrm{H} 3$ is not required to block NROB1 expression in vivo. In contrast, either $\mathrm{H} 3 \mathrm{~K} 9 \mathrm{me} 2$ or $\mathrm{H} 3 \mathrm{~K} 27 \mathrm{me} 3$ may participate in inhibiting NROB1 gene expression in vivo (Figure 9A-9B).

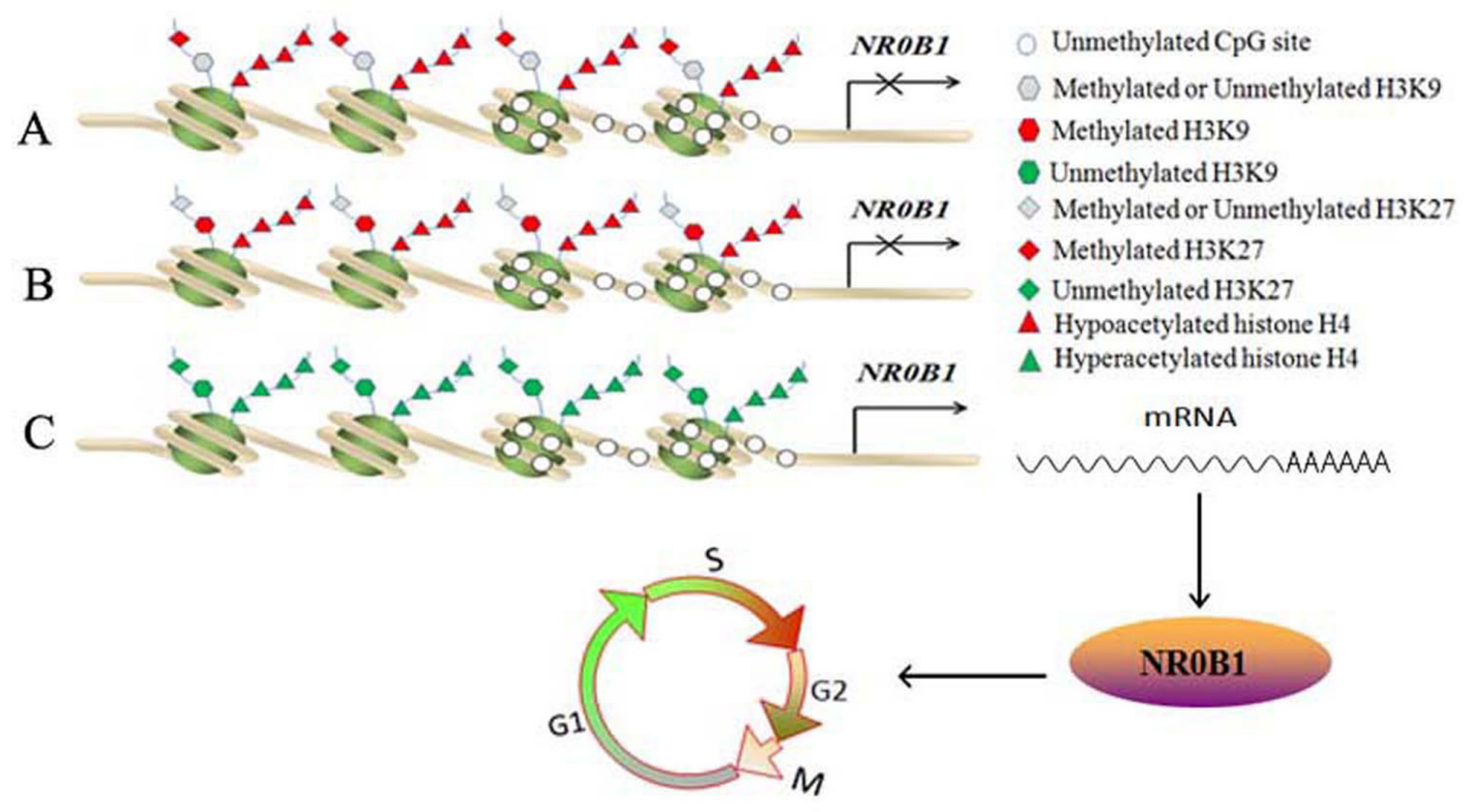

Promote cell self-renewal

Figure 9: Proposed model for the in vivo epigenetic regulation of NROB1 expression. A-B. Hypoacetylation of histone H4 and H3K9me2 (A) / H3K27me3 (B) binding to the NROB1 promoter silences NROB1 transcription, although the NROB1 CGI is unmethylated. C. In addition to unmethylated the NROB1 CGIs, hyperacetylated histone H4 and the demethylated lysines 9 and 27 of histone H3 on the $N R O B 1$ promoter facilitate its activation to promote cell self-renewal. 
In summary, this study demonstrates a number of epigenetic regulatory mechanisms that affect $N R O B 1$ expression (Figure 9). In vivo, we found that DNA methylation was not involved in regulating NROBI transcription, although the hypermethylation of the NROB1 CGI silenced its expression in vitro. In general, the hypoacetylation of histone $\mathrm{H} 4$ and $\mathrm{H} 3 \mathrm{~K} 9 \mathrm{me} 2$ or $\mathrm{H} 3 \mathrm{~K} 27 \mathrm{me} 3$ binding to the NROB1 promoter silenced its transcription in normal tissues and cells. Once the hyper acetyl-histone $\mathrm{H} 4$ and the unmethylated histones H3K9 and H3K27 became enriched in the NROB1 promoter region, its transcription was activated (Figure 9C). Thus, in ADCA, the activation of NR0B1 may promote the selfrenewal of cancer cells.

\section{MATERIALS AND METHODS}

\section{Human samples}

One hundred and sixty cancer tissues and paired adjacent noncancerous tissues (male: 83 cases; female: 77 cases) were obtained from ADCA patients who obtained a histopathologic diagnosis from 2007-2010 at the Department of Pathology, West China Hospital, Sichuan University, China. The clinical stages of the ADCA patients, including stage I (5 cases), stage II (115 cases) and stage III (40 cases), were confirmed using pathology. The ages of the ADCA patients ranged from 41 to 76 years old. Using the Decision Tree addon module in the statistical package SPSS 17.0, we divided the ADCA patients into two groups ( $\leq 65$ and $>$ 65 years old). No correlation was observed between age and gender, between age and clinical stage or between age and NR0B1 expression level (Table S1). Human testicular biopsies were obtained from two obstructive azoospermic patients with normal spermatogenesis. Peripheral blood samples were collected from 10 volunteers ( 5 males and 5 females). Written informed consent was obtained from each participant.

\section{Mouse samples}

All mouse samples were obtained from wild-type C57BL/6J mice that were bred in the Laboratory Animal Center of the State Key Laboratory of Biotherapy, Sichuan University. This study was authorized by the Ethical Committee of West China Hospital, Sichuan University.

\section{Cell lines}

The human cell lines, including 293T (embryo kidney cell), A549 (ADCA cell), HepG2 (hepatocellular carcinoma cell), LNCaP, PC-3 and DU145 (prostate cancer cells), and the SKOV-3 (oophoroma cells), MCF7 (breast cancer cell), and HeLa (cervical cancer cell) cells were originally purchased from the American Type Culture
Collection (ATCC, Manassas VA, USA) and maintained in our laboratory until used in the current study.

\section{Antibodies}

Rabbit polyclonal antibodies for NR0B1 (ab60144), NR5A1 (ab65815), and acetyl-histone H3 (ab47915); rabbit monoclonal antibodies for NR5A2 (ab125034), NANOG (ab109250), OCT3/4 (ab109183), AR (ab133273), SOX2 (ab92494), and STAT3 (ab68153); and mouse monoclonal antibodies for H3K4me3 (ab6000), H3K9me2 (ab1220), H3K27me3 (ab6002), $\alpha$-TUBULIN (ab7750) and glyceraldehyde-3-phosphate dehydrogenase (GAPDH, ab9482) were obtained from Abcam (Cambridge, MA). The rabbit polyclonal antibody for acetyl-histone $\mathrm{H} 4$ (06-598) was purchased from Millipore (Temecula, CA). The mouse monoclonal antiFLAG antibody (F1804) was purchased from SigmaAldrich (St. Louis, MO).

\section{Immunohistochemical (IHC) analysis}

To detect the NR0B1 protein in ADCA tissues, 5- $\mu \mathrm{m}$ sections of paraffin-embedded tissues were deparaffinized, rehydrated, and treated with hydrogen peroxide. After antigen retrieval was performed using citrate buffer and microwave boiling, the sections were incubated with anti-NR0B1 rabbit polyclonal antibodies at a dilution of 1:200 at $4^{\circ} \mathrm{C}$ overnight. Sections were then washed in PBS and incubated in horseradish-peroxidase-conjugated goat anti-rabbit IgG followed by incubation with 3 , 3 '-diaminobenzidine (DAB) substrate and counterstaining with hematoxylin solution. Pre-immune rabbit serum was used as the primary antibody for the negative controls. The level of NR0B1 staining was scored by two independent examiners and classified into three subgroups: (i) negative $(-)$, when the NR0B1 signal was almost undetectable and the number of cells displaying NR0B1 signal was less than $1 \%$; (ii) moderate $(+)$, when the NR0B1 signal was moderate and the number of cells displaying NR0B1 signal was 1-50\%; and (iii) strong $(++)$, when the NR0B1 signal was strong and the number of cells displaying NR0B1 signal was greater than 50\%.

\section{Immunoblotting (IB) analysis}

Lysates that were extracted from tissues and cells were separated on 10\% SDS-polyacrylamide gels and then transferred onto polyvinylidene difluoride (PVDF) membrane (Millipore). After blocking the membranes in $10 \%$ dry milk, the transferred membranes were sequentially incubated with primary antibodies and horseradish peroxidase (HRP)-conjugated secondary antibodies. Immunoreactive bands were identified using a chemiluminescent HRP substrate kit (Millipore). $\alpha$-TUBULIN and GAPDH were used as the internal references. The relative NR0B1 protein levels (vs. 
GAPDH or TUBULIN) were calculated using Image J software.

\section{Bisulfite genomic DNA sequencing}

Genomic DNA was extracted from tissues and cells using a Tissue DNA Kit (BioTeke Corporation, Beijing, China), and bisulfite treatment was performed using a DNA Methylation-Gold Kit (Zymo research, Irvine, CA) according to the manufacturer's instructions. The primers used for polymerase chain reaction (PCR) are shown in supplementary Table S2. All PCR products were separated on agarose gels, recovered and inserted into a T-vector (TaKaRa Bio, Dalian). More than 20 clones for each DNA sample were sequenced using T7/M13 universal primers.

\section{Chemical treatments}

In the experiments designed to determine the effect of epigenetic factors on the expression of the NROB1 gene, cells were treated separately or simultaneously with the DNA methyltransferase inhibitor 5'-aza-2'-deoxycytidine (AZA, Sigma-Aldrich), the HDAC inhibitor trichostatin A (TSA, Sigma-Aldrich), and the HMTase inhibitors DZNep (Selleckchem) and BIX01294 (Selleckchem), as previously described $[44,22]$.

\section{RNA isolation and quantitative reverse transcription PCR (qRT-PCR)}

Total RNA was isolated from cell lines and tissues using a Super-Purity RNA Exaction Kit (BioTeke). Firststrand cDNA was reverse transcribed using a RevertAid First-Strand cDNA Synthesis Kit (ThermoFisher, Waltham, MA). The primers that were used for RT-PCR and qRT-PCR are listed in supplementary Table S2. The $G A P D H$ gene was used as an internal control.

Quantitative RT-PCR was performed using the SYBR Premix Ex Taq II (TaKaRa Bio). Reactions were run using a Bio-Rad iCycler RT-PCR Detection System. The $\Delta \Delta \mathrm{CT}$ method was used for data analysis. Each assay was performed in triplicate using each sample.

\section{Isolation of a side population (SP) from A549 cells}

The SP and main population (MP) of A549 cells were isolated using fluorescence activated cell sorting (FACS, Navios MoFlo XDP, Beckman Coulter, Fullerton, CA) with Hoechst 33342 dye according to previous reports $[7,45]$.

\section{Chromatin immunoprecipitation (ChIP) and quantitative PCR (qPCR)}

ChIP assays were performed using a ChIP-IT Express Enzymatic Kit (Active Motif, Carlsbad, CA).
Briefly, the cells were first fixed with formaldehyde, and then the cross-linked chromatin was digested using an enzymatic shearing cocktail. A portion of optimally sheared chromatin was kept for use as a control "input DNA" in the subsequent qPCR analysis. The remaining sheared chromatin was precipitated by incubation with antibodies against acetyl-histone $\mathrm{H} 3$, acetyl-histone H4, H3K4me3, H3K9me2 and H3K27me3. qPCR was performed to amplify the target region of the $N R O B 1$ promoter. The CT values from each run were averaged per tissue or cell, and the $\Delta \Delta C T$ method was then used for the data analysis, in which the value of target DNA fragments that were enriched in each tissue or cell was normalized to the value of the $5 \%$ input DNA of each sample. The qPCR data were expressed as the means \pm standard deviations (S.D.). The ChIP-qPCR assay was repeated twice to confirm the reproducibility of the results.

\section{Statistical analysis}

Pearson's chi-squared tests were used to calculate the differences in the expression of NR0B1 between different genders and clinical stages. Student's $t$-test was used in all other comparisons. A $p$ value of less than 0.05 was considered significant. R program (version 3.2.2) and GraphPad Prism 5 software were used for the statistical analysis.

\section{ACKNOWLEDGMENTS}

We are grateful to the study participants and their families for their cooperation. We thank the staff of the Department of Pathology and the Department of Thoracic Surgery, West China Hospital, Sichuan University, China, for collecting the samples and verifying the clinical stages of the lung adenocarcinoma samples. We also thank Dr. Fangfang Wang from the Hematology Research Laboratory, Department of Hematology, West China Hospital, for support during the FACS analysis. We would also like to thank Dr. Cuiying Xiao from the Diabetes, Endocrinology, and Obesity Branch of the National Institute of Diabetes and Digestive and Kidney Diseases at the NIH (USA) for providing instructive guidance regarding the preparation of this manuscript.

\section{CONFLICTS OF INTEREST}

The authors declare that they have no conflicts of interest.

\section{FUNDS}

This work was supported by research grants from the National Natural Science Foundation of China (81370748 and 81471430). 


\section{REFERENCES}

1. Swain A, Narvaez V, Burgoyne P, Camerino G, LovellBadge R. Dax 1 antagonizes Sry action in mammalian sex determination. Nature. 1998; 391: 761-767.

2. Saito S, Ito K, Suzuki T, Utsunomiya H, Akahira J, Sugihashi Y, Niikura H, Okamura K, Yaegashi N, Sasano H. Orphan nuclear receptor DAX-1 in human endometrium and its disorders. Cancer Sci. 2005; 96: 645-652.

3. Abd-Elaziz M, Akahira J, Moriya T, Suzuki T, Yaegashi $\mathrm{N}$, Sasano H. Nuclear receptor DAX-1 in human common epithelial ovarian carcinoma: an independent prognostic factor of clinical outcome. Cancer Sci. 2003; 94: 980-985.

4. Nakamura Y, Suzuki T, Arai Y, Sasano H. Nuclear receptor DAX1 in human prostate cancer: a novel independent biological modulator. Endocr J. 2009; 56: 39-44.

5. Mendiola M, Carrillo J, García E, Lalli E, Hernández T, de Alava E, Tirode F, Delattre O, García-Miguel P, LópezBarea F, Pestaña A, Alonso J. The orphan nuclear receptor DAX1 is up-regulated by the EWS/FLI1 oncoprotein and is highly expressed in Ewing tumors. Int J Cancer. 2006; 118: 1381-1389.

6. Kinsey M, Smith R, Lessnick SL. NR0B1 is required for the oncogenic phenotype mediated by EWS/FLI in Ewing's sarcoma. Mol Cancer Res. 2006; 4: 851-859.

7. Oda $\mathrm{T}$, Tian $\mathrm{T}$, Inoue $\mathrm{M}$, Ikeda J, Qiu Y, Okumura M, Aozasa K, Morii E. Tumorigenic role of orphan nuclear receptor NR0B1 in lung adenocarcinoma. Am J Pathol. 2009; 175: 1235-1245.

8. Zhang H, Slewa A, Janssen E, Skaland I, Yu Y, Gudlaugsson E, Feng W, Kjellevold K, Søiland H, Baak JP. The prognostic value of the orphan nuclear receptor DAX-1 (NROB1) in node-negative breast cancer. Anticancer Res. 2011; 31: 443-449.

9. Jiang HL, Xu D, Yu H, Ma X, Lin GF, Ma DY, Jin JZ. DAX-1 inhibits hepatocellular carcinoma proliferation by inhibiting $\beta$-catenin transcriptional activity. Cell Physiol Biochem. 2014; 34: 734-742.

10. de Smet C, Lurquin C, Lethé B, Martelange V, Boon T. DNA methylation is the primary silencing mechanism for a set of germ line- and tumor-specific genes with a CpG-rich promoter. Mol Cell Biol. 1999; 19: 7327-7335.

11. Kim J, Chu J, Shen X, Wang J, Orkin SH. An extended transcriptional network for pluripotency of embryonic stem cells. Cell. 2008; 132: 1049-1061.

12. Lanzino M, Maris P, Sirianni R, Barone I, Casaburi I, Chimento A, Giordano C, Morelli C, Sisci D, Rizza P, Bonofiglio D, Catalano S, Andò S. DAX-1, as an androgentarget gene, inhibits aromatase expression: a novel mechanism blocking estrogen-dependent breast cancer cell proliferation. Cell Death Dis. 2013; 4: e724.

13. Hoyle C, Narvaez V, Alldus G, Lovell-Badge R, Swain A. Dax 1 expression is dependent on steroidogenic factor 1 in the developing gonad. Mol Endocrinol. 2002; 16: 747-756.
14. Uranishi K, Akagi T, Sun C, Koide H, Yokota T. Dax1 associates with Esrrb and regulates its function in embryonic stem cells. Mol Cell Biol. 2013; 33: 2056-2066.

15. Sun C, Nakatake Y, Ura H, Akagi T, Niwa H, Koide $\mathrm{H}$, Yokota T. Stem cell-specific expression of Dax 1 is conferred by STAT3 and Oct 3/4 in embryonic stem cells. Biochem Biophys Res Commun. 2008; 372: 91-96.

16. Momparler RL. Cancer epigenetics. Oncogene. 2003; 22: 6479-6483.

17. Walton TJ, Li G, Seth R, McArdle SE, Bishop MC, Rees RC. DNA demethylation and histone deacetylation inhibition co-operate to re-express estrogen receptor beta and induce apoptosis in prostate cancer cell-lines. Prostate. 2008; 68: 210-222.

18. Ou JN, Torrisani J, Unterberger A, Provençal N, Shikimi K, Karimi M, Ekström TJ, Szyf M. Histone deacetylase inhibitor Trichostatin A induces global and gene-specific DNA demethylation in human cancer cell lines. Biochem Pharmacol. 2007; 73: 1297-1307.

19. Arzenani MK, Zade AE, Ming Y, Vijverberg SJ, Zhang Z, Khan Z, Sadique S, Kallenbach L, Hu L, Vukojević V, Ekström TJ. Genomic DNA hypomethylation by histone deacetylase inhibition implicates DNMT1 nuclear dynamics. Mol Cell Biol. 2011; 31: 4119-4128.

20. Jenuwein $\mathrm{T}$. The epigenetic magic of histone lysine methylation. FEBS J. 2006; 273: 3121-3135.

21. Tan J, Yang X, Zhuang L, Jiang X, Chen W, Lee PL, Karuturi RK, Tan PB, Liu ET, Yu Q. Pharmacologic disruption of polycomb-repressive complex 2-mediated gene repression selectively induces apoptosis in cancer cells. Genes Dev. 2007; 21: 1050-1063.

22. Kubicek S, O'Sullivan RJ, August EM, Hickey ER, Zhang Q, Teodoro ML, Rea S, Mechtler K, Kowalski JA, Homon CA, Kelly TA, Jenuwein T. Reversal of H3K 9me2 by a small-molecule inhibitor for the G9a histone methyltransferase. Mol Cell. 2007; 25: 473-481.

23. Martins RS, Power DM, Fuentes J, Deloffre LA, Canário AV. DAX1 regulatory networks unveil conserved and potentially new functions. Gene. 2013; 530: 66-74.

24. Niakan KK, Davis EC, Clipsham RC, Jiang M, Dehart DB, Sulik KK, McCabe ER. Novel role for the orphan nuclear receptor Dax1 in embryogenesis, different from steroidogenesis. Mol Genet Metab. 2006; 88: 261-271.

25. Zhang J, Liu G, Ruan Y, Wang J, Zhao K, Wan Y, Liu B, Zheng H, Peng T, Wu W, He P, Hu FQ, Jian R. Dax1 and Nanog act in parallel to stabilize mouse embryonic stem cells and induced pluripotency. Nat Commun. 2014; 5: 5042 .

26. Kelly VR, Hammer GD. LRH-1 and Nanog regulate Dax1 transcription in mouse embryonic stem cells. Mol Cell Endocrinol. 2011; 332: 116-124.

27. Fujii S, Nishikawa-Torikai S, Futatsugi Y, Toyooka Y, Yamane M, Ohtsuka S, Niwa H. NrObl is a negative 
regulator of Zscan4c in mouse embryonic stem cells. Sci Rep. 2015; 5: 9146.

28. Niakan KK, McCabe ER. DAX1 origin, function, and novel role. Mol Genet Metab. 2005; 86: 70-83.

29. Honda S, Loher P, Shigematsu M, Palazzo JP, Suzuki R, Imoto I, Rigoutsos I, Kirino Y. Sex hormone-dependent tRNA halves enhance cell proliferation in breast and prostate cancers. Proc Natl Acad Sci USA. 2015; 112: E3816-E3825.

30. Nandy SB, Gangwani L, Nahleh Z, Subramani R, Arumugam A, de la Rosa JM, Lakshmanaswamy R. Recurrence and metastasis of breast cancer is influenced by ovarian hormone's effect on breast cancer stem cells. Future Oncol. 2015; 11: 983-995.

31. Ren X, Wu X, Hillier SG, Fegan KS, Critchley HO, Mason JI, Sarvi S, Harlow CR. Local estrogen metabolism in epithelial ovarian cancer suggests novel targets for therapy. J Steroid Biochem Mol Biol. 2015; 150: 54-63.

32. Stabile LP, Davis AL, Gubish CT, Hopkins TM, Luketich JD, Christie N, Finkelstein S, Siegfried JM. Human nonsmall cell lung tumors and cells derived from normal lung express both estrogen receptor alpha and beta and show biological responses to estrogen. Cancer Res. 2002; 62: 2141-2150.

33. Ishibashi H, Suzuki T, Suzuki S, Niikawa H, Lu L, Miki Y, Moriya T, Hayashi S, Handa M, Kondo T, Sasano H. Progesterone receptor in non-small cell lung cancer-a potent prognostic factor and possible target for endocrine therapy. Cancer Res. 2005; 65: 6450-6458.

34. Omoto Y, Kobayashi Y, Nishida K, Tsuchiya E, Eguchi H, Nakagawa K, Ishikawa Y, Yamori T, Iwase H, Fujii Y, Warner M, Gustafsson JA, Hayashi SI. Expression, function, and clinical implications of the estrogen receptor beta in human lung cancers. Biochem Biophys Res Commun. 2001; 285: 340-347.

35. Ehrlich M. DNA hypomethylation in cancer cells. Epigenomics. 2009; 1: 239-259.

36. Strahl BD, Allis CD. The language of covalent histone modifications. Nature. 2000; 403: 41-45.

37. Sarg B, Helliger W, Talasz H, Koutzamani E, Lindner HH. Histone H4 hyperacetylation precludes histone H4 lysine 20 trimethylation. J Biol Chem. 2004; 279: 53458-53464.
38. Plotnikov AN, Yang S, Zhou TJ, Rusinova E, Frasca A, Zhou MM. Structural insights into acetylated-histone H4 recognition by the bromodomain-PHD finger module of human transcriptional coactivator CBP. Structure. 2014; 22: $353-360$.

39. Guo W, Lu J, Dai M, Wu T, Yu Z, Wang J, Chen W, Shi D, Yu W, Xiao Y, Yi C, Tang Z, Xu T, Xiao X, Yuan Y, Liu Q, Du G, Deng W. Transcriptional coactivator CBP upregulates hTERT expression and tumor growth and predicts poor prognosis in human lung cancers. Oncotarget. 2014; 5: 9349-9361. doi: 10.18632/oncotarget.2430.

40. Wan J, Zhan J, Li S, Ma J, Xu W, Liu C, Xue X, Xie Y, Fang W, Chin YE, Zhang H. PCAF-primed EZH2 acetylation regulates its stability and promotes lung adenocarcinoma progression. Nucleic Acids Res. 2015; 43: 3591-3604.

41. Tang Z, Yu W, Zhang C, Zhao S, Yu Z, Xiao X, Tang R, Xuan Y, Yang W, Hao J, Xu T, Zhang Q, Huang W, Deng W, Guo W. CREB-binding protein regulates lung cancer growth by targeting MAPK and CPSF4 signaling pathway. Mol Oncol. 2016; 10: 317-329.

42. Qin Y, Chen W, Xiao Y, Yu W, Cai X, Dai M, Xu T, Huang W, Guo W, Deng W, Wu T. RFPL3 and CBP synergistically upregulate hTERT activity and promote lung cancer growth. Oncotarget. 2015; 6: 27130-27145. doi: 10.18632/oncotarget.4825.

43. Margueron R, Trojer P, Reinberg D. The key to development: interpreting the histone code? Curr Opin Genet Dev. 2005; 15: 163-176.

44. Rao M, Chinnasamy N, Hong JA, Zhang Y, Zhang M, Xi S, Liu F, Marquez VE, Morgan RA, Schrump DS. Inhibition of histone lysine methylation enhances cancertestis antigen expression in lung cancer cells: implications for adoptive immunotherapy of cancer. Cancer Res. 2011; 71: 4192-4204.

45. Nakatsugawa M, Takahashi A, Hirohashi Y, Torigoe T, Inoda S, Murase M, Asanuma H, Tamura Y, Morita R, Michifuri Y, Kondo T, Hasegawa T, Takahashi H, Sato N. SOX2 is overexpressed in stem-like cells of human lung adenocarcinoma and augments the tumorigenicity. Lab Invest. 2011; 91: 1796-1804. 